
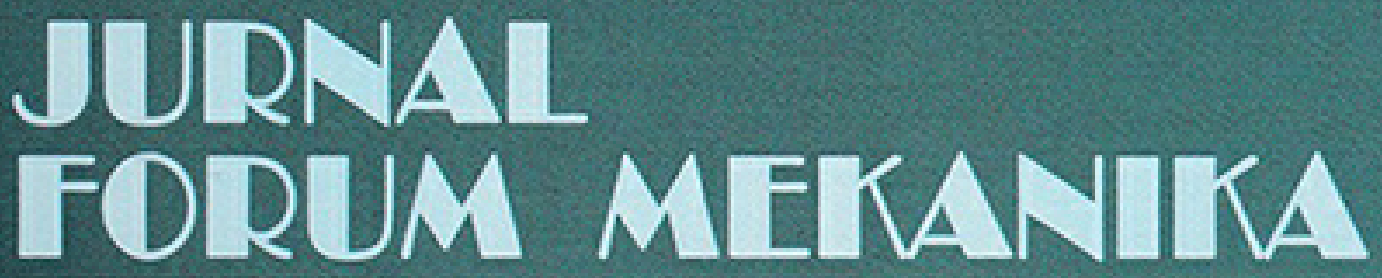

Volume 6 - Nomor 2 November 2017 ISSN : 2356-1491

ANALISIS RUMAH KABEL BAWAH TANAH PADA PROYEK PEKERJAAN JARINGAN UTILITAS SKTT 150 KV PLUMPANG - GAMBIR DYAH PRATIWI KUSUMASTUTI; IRMA SEPRIYANNA

STUDI KOMPARASI ANTARA PRACETAK MASIF DAN FLY SLAB STUDI KASUS: STRUKTUR GEDUNG RUSUNAWA SURAKARTA BUDI WICAKSONO

SISTEM DRAINASE ALIRAN BAWAH TANAH UNTUK DAERAH RAWAN LONGSOR (STUDI KASUS SUB DAS SUNGAI CIKAPUNDUNG, BANDUNG) ENDAH LESTARI

ANALISA STATISTIK DEBIT BANIIR DAN DEBIT ANDALAN SUNGAI KOMERING SUMATERA SELATAN DEVITA MAYASARI

STUDI EKSPERIMENTAL KUAT LENTUR BAJA PROFIL I KOMPAK SIMETRIS GANDA BERDASARKAN RSNI 03-1729-201X

DICKI DIAN PURNAMA; AKHMAD AMINULLAH; MUSLIKH

PENGGUNAAN PASIR LAUT TERHADAP KUAT TEKAN BETON KOTA BENGKULU TOMMYIDUWIN

ANALISA PENGARUH ADMIXTURE TERHADAP ABU TERBANG (FLY ASH) DAN BOTTOM ASH

TRI YUHANAH; NOVIA ADE MANDASARI

ANALISA KINERJA PERSIMPANGAN BERSINYAL PADA PERSIMPANGAN ANGKATAN 66 DAN RUAS JALAN R. SOEKAMTO KOTA PALEMBANG YULES PRAMONA ZULKARNAIN; IRMA INDRIANI 


\title{
ANALISA PENGARUH ADMIXTURE TERHADAP ABU TERBANG (FLY ASH) DAN BOTTOM ASH
}

\author{
TRI YUHANAH \\ Jurusan Teknik Sipil, Sekolah Tinggi Teknik - PLN Jakarta \\ E-mail : triyuhanah@gmail.com \\ NOVIA ADE MANDASARI \\ Jurusan Teknik Sipil, Sekolah Tinggi Teknik - PLN Jakarta \\ E-mail : noviaade95@gmail.com
}

\begin{abstract}
Abstrak
Untuk meningkatkan kualitas beton yaitu dengan menggunakan penambahan admixture. Dengan menambah admixture Silica fume dan superplasticizer diharapkan dapat meningkatkan mutu beton pada beton yang menggunakan limbah abu terbang (fly ash) dan bottom ash.Tujuan utama dari penelitian ini adalah untuk mengetahui nilai kuat tekan beton, nilai slump test, suhu beton segar dan setting time pada beton yang menggunakan limbah abu terbang (fly ash) dan bottom ash sebesar 0\%, 5\%, 10\%, 15\%, 20\% dan 25\% dari berat semen, dengan variasi silica fume 0\%, 2\%, 4\%, 6\%, 8\%, 10\% dari berat semen yang sudah dikurangi dengan berat fly ash dan bottom ash dan ditambah dengan superplasticizer sebesar $2 \%$ dari kebutuhan air. Mutu beton yang direncanakan 41,7 MPa pada umur 28 hari, dengan sampel diuji pada umur 7, 14, 28 hari. Berdasarkan hasil pengujian kuat tekan beton tertinggi untuk beton abu terbang (fly ash) terdapat pada variasi campuran FA 10\%, SP 4\%, SF 2\% yaitu sebesar 56,16 MPa. Dan untuk campuran bottom ash kuat tekan tertinggi pada variasi campuran BA 5\%, SF 2\%, SP 2\% yaitu sebesar 49,82 MPa. Suhu beton segar variasi campuran FA 5\%, SF 2\%, SP 2\% dan BA 5\%, SF 2\%, SP 2\% naik satu derajat dari suhu beton normal. Setting time yang dihasilkan pada beton campuran FA 5\%, SF 2\%, SP 2\% memiliki waktu tercepat initial setting yaitu 251 menit dari semua variasi campuran beton.
\end{abstract}

Kata kunci : admixture, fly ash, bottom ash, kuat tekan, setting time

\begin{abstract}
With improve the quality of concrete is by using the addition of admixture. By adding admixture Silica fume and superplasticizer is expected to improve concrete quality in concrete using fly ash and bottom ash. The main objective of this research is to know the value of concrete compressive strength, slump test value, fresh concrete temperature and setting time in concrete using fly ash and bottom ash by 0\%, 5\%, 10\%, 15\%, 20\% and 25\% by weight of cement, with variations of silica fume 0\%, 2\%, 4\%, 6\%,8\%, $10 \%$ of the weight of cement that has been reduced by the weight of fly ash and bottom ash and added with superplasticizer of $2 \%$ of the water requirement. The planned concrete quality was $41.7 \mathrm{MPa}$ at 28 days, with the sample tested at age 7, 14, 28 days. Based on the results of the highest concrete compressive strength test for fly ash concrete (fly ash) is found in FA mixture variation 10\%, SP 4\%, SF 2\% that is equal to 56,16 MPa. And for mixed bottom ash the highest compressive strength on mixed variation of BA 5\%, SF 2\%, SP 2\% is equal to 49,82 MPa. Fresh concrete temperature variation of FA mixture 5\%, SF 2\%, SP $2 \%$ and BA 5\%, SF 2\%, SP 2\% rose one degree from normal concrete temperature. Setting time generated on mixed concrete FA 5\%, SF 2\%, SP 2\% has the fastest initial time setting ie 251 minutes of all variations of concrete mix.
\end{abstract}

Keywords: admixture, fly ash, bottom ash, compressive strength, setting time

\section{Latar Belakang}

Beton merupakan suatu material campuran yang terdiri dari pasir (agregat halus), kerikil (agregat kasar), semen, air dan dengan atau tanpa bahan tambahan (admixture) dengan perbandingan tertentu yang akan membentuk beton segar. Kualitas dari beton segar yang baik akan sangat berpengaruh terhadap kuat tekan beton, untuk itu telah dilakukan banyak penelitian dan inovasi tentang beton terhadap bahan pengganti atau bahan tambah pada komponen penyusunan beton yang akan berpengaruh pada kuat tekan beton. Dalam penelitian kali ini, memanfaatkan limbah abu terbang (fly ash) dan bottom ash dari PLTU Air Anyir - Bangka, dimana limbah ini mengalami peningkatan dari hari ke hari, maka perlu penanganan yang tepat guna. Limbah abu terbang (fly ash) dan bottom ash berdampak pada lingkungan yang cukup membahayakan yaitu mengakibatkan polusi udara. Oleh karena itu, 
diupayakan mencari manfaat abu terbang (fly ash) dan bottom ash menjadi bahan yang berguna yaitu sebagai bahan campuran dari beton. Abu terbang (fly ash) adalah sisa pembakaran batubara yang keluar dari tungku pembakaran, sedangkan sisa pembakaran batu bara yang berada pada dasar tungku disebut bottom ash. Bottom ash memiliki partikel lebih besar dan lebih berat dari pada abu terbang (fly ash). Sifat dari abu terbang (fly ash) dan bottom ash sangat bervariasi karena dipengaruhi oleh jenis batu bara dan sistem pembakarannya. Abu terbang (fly ash) dan bottom ash digunakan pada campuran beton sebagai bahan pengganti dari semen. Untuk bottom ash, dapat dimanfaatkan sebagai agregat dalam campuran semen dan beton.

Penelitian ini akan menggunakan bahan tambah seperti silica fume dan superplasticizer. Silicafume sendiri merupakan produk sampingan sebagai abu pembakaran dari proses pembuatan silicon metal atau silicon alloy dalam tungku pembakaran listrik. Mikrosilika ini bersifat pozzolan, dengan kadar kandungan senyawa silica-dioksida $\left(\mathrm{SiO}_{2}\right)$ yang sangat tinggi (>90\%) dan ukuran butiran partikel yang sangat halus, yaitu sekitar 1/100 ukuran ratarata partikel semen. Dengan demikian penggunaan mikrosilika pada umumnya akan memberikan sumbangan yang lebih efektif pada kinerja beton, terutama untuk beton bermutu sangat tinggi. Selain itu juga dapat meningkatnya ikatan pasta beton dengan agregat yang menghasilkan kekuatan beton lebih tinggi. Maka dari itu, untuk penggunaan silica fume sendiri untuk mengurangi jumlah semen pada campuran beton, sehingga dapat menanggulangi dampak pemakaian semen yang terlalu banyak. Superplasticizer dalam campuran beton bisa mempermudah pelaksanaan serta mengurangi penggunaan air (dengan menggunakan faktor air semen kecil) pada beton sehingga beton memiliki mutu kekentalan yang tinggi. Mengurangi air pada beton itu sendiri untuk mendapatkan beton bermutu tinggi dan mencegah terjadinya keroposan akibat pemadatan yang tidak maksimal. Bahan superplasticizeryang akan digunakan dalam penelitian ini adalah sika viscocrete-3115N.

Pada penelitian ini dilihat berapa pengaruh perbandingan limbah abu terbang (fly ash) dan bottom ash PLTU Air Anyir - Bangka dengan kadar $0 \%, 5 \%, 10 \%, 15 \%, 20 \%, 25 \%$ dari berat semen dengan kombinasi variasi silicafume dengan kadar $0 \%, 2 \%, 4 \%, 6 \%, 8 \%, 10 \%$ dari berat semen yang sudah dikurangi dengan berat semen fly ash, dan ditambah dengan superplasticizer dengan kadar $2 \%$ dari kebutuhan air, terhadap slump test, suhu beton saat pengecoran, kuat tekan beton, serta setting timenya. Bagaimana perbandingan grafik slump test, suhu beton saat pengecoran dan kuat tekan maupun setting time terhadap limbah abu terbang (fly ash) dan bottom ash PLTU Air Anyir - Bangka.

Tujuan utama penelitian ini adalah untuk mendapatkan perbandingan suhu pada saat pengecora, nilai slump test, nilai kuat tekan beton, serta setting time dengan perbandingan limbah abu terbang (fly ash) dan bottom ash sebesar 0\%, 5\%, $10 \%, 15 \%, 20 \%$ dan $25 \%$ dari berat semen, yang dikombinasi dengan variasi silica fume $0 \%, 2 \%, 4 \%$, $6 \%, 8 \%, 10 \%$ dari berat semen yang sudah dikurangi dengan berat semen fly ash dan bottom ash, dan ditambah dengan superplasticizer sebesar $2 \%$ dari kebutuhan air.

\section{Landasan Teori}

\section{Komponen-Komponen Penyusun Beton}

Beton adalah campuran semen Portland, air , dan agregat dengan atau tanpa bahan tambahan (admixture) tertentu. Material pembentuk beton tersebut dicampur merata dengan komposisi tertentu yang menghasilkan suatu campuran yang homogen sehingga dapat dituang dalam cetakan untuk dibentuk sesuai keinginan. Pemilihan bahan-bahan pembentuk beton yang mempunyai kualitas baik, perhitungan proporsi campuran yang tepat. Cara pengerjaan dan perawatan yang baik dan penambahan bahan tambah yang tepat dengan kadar yang optimum yang diperlukan akan menentukan kualitas beton yang dihasilkan. Berikut ini adalah penjelasan tentang bahan-bahan yang digunakan untuk membuat beton.

\section{Semen Portland}

Semen PPC dibuat dari semen hidraulis yang dihasilkan dengan cara menghaluskan klinker yang terbuat dari batu kapur $\left(\mathrm{CaCO}_{3}\right)$ yang jumlahnya sangat banyak serta tanah liat dan bahan dasar berkadar besi, terutama dari silikat-silikat kalsium yang bersifat hidraulis ditambah dengan bahan yang mengatur waktu ikat. Semen portland dibuat dengan melalui beberapa langkah, sehingga sangat halus dan memiliki sifat adhesif maupun kohesif. Bahan dasar semen Portland terdiri dari bahan-bahan yang mengandung kapur, silika, alumina, dan oksida besi

\begin{abstract}
Air
Dalam pembuatan beton, air merupakan faktor yang sangat penting karena air dapat bereaksi dengan semen yang akan menjadi pasta pengikat agregat. Air juga berpengaruh terhadap kuat desak beton, karena jika kelebihan penggunaan air akan berakibat pada penurunan kekuatan beton tersebut. Sebaliknya jika kelebihan penggunaan air akan mengakibatkan beton menjadi bleeding, yaitu air bersama sama dengan semen akan naik ke atas permukaan adukan segar yang baru dituang. Berdasarkan SNI $2847: 2013^{[1]}$ air yang digunakan pada campuran beton harus memenuhi ASTM C1602M (Standar Spesifikasi untuk Air Campuran yang Digunakan dalam Produksi Beton Semen Hidrolis). Air untuk pembuatan beton minimal memenuhi syarat sebagai air minum yaitu tawar, tidak berbau, bila dihembuskan dengan udara tidak keruh dan lain-lain.
\end{abstract}




\section{Agregat}

Agregat merupakan butiran mineral alami yang berfungsi sebagai bahan pengisian dalam campuran mortar dan beton. Agregat ini akan menempati sebanyak $60 \%$ sampai $80 \%$ dari volume mortar atau beton. Meskipun hanya sebagai bahan pengisi, namun agregat sangat berpengaruh terhadap sifat mortar atau beton, sehingga pemilihan agregat merupakan suatu bagian penting dalam pembuatan mortar atau beton. Berdasarkan ukuran butirnya, agregat yang dipakai dalam adukan beton dibedakan menjadi dua jenis yaitu agregat kasar dan agregat halus. Cara membedakan jenis agregat yang paling banyak dilakukan adalah dengan berdasarkan pada ukuran butiran-butirannya. Agregat yang mempunyai butiran-butiran yang besar disebut agregat kasar yang ukurannya lebih besar dari 4,75 $\mathrm{mm}$. Sedangkan butiran agregat yang kecil disebut agregat halus yang memiliki ukuran lebih kecil dari 4,75 mm. Untuk menghasilkan beton dengan kekompakkan yang baik, diperlukan gradasi agregat yang baik.

Berdasarkan ukurannya, agregat terbagi dua jenis, yaitu :

1. Agregat halus merupakan pasir alam sebagai hasil disintegrasi 'alami' dari batuan atau pasir yang dihasilkan oleh industri pemecah batu dan mempunyai ukuran butir terbesar 5,0 $\mathrm{mm}^{[2]}$.

Tabel 1. Gradasi Jenis Kategori Zona Kehalusan Pasir

\begin{tabular}{|c|c|c|c|c|c|c|c|c|}
\hline \multirow{2}{*}{$\begin{array}{c}\text { Ayaka } \\
\mathrm{n} \\
(\mathrm{mm})\end{array}$} & \multicolumn{2}{|c|}{$\begin{array}{c}\text { Zona1 } \\
\text { (Kasar) }\end{array}$} & $\begin{array}{c}\text { Zona 2 } \\
\text { (Agak Kasar) }\end{array}$ & \multicolumn{2}{c|}{$\begin{array}{c}\text { Zona 3 } \\
\text { (Halus) }\end{array}$} & \multicolumn{2}{c|}{$\begin{array}{c}\text { Zona 4 } \\
\text { (Agak Halus) }\end{array}$} \\
\cline { 2 - 10 } & $\begin{array}{c}\text { Bawa } \\
\mathrm{h}\end{array}$ & $\begin{array}{c}\text { Ata } \\
\mathrm{s}\end{array}$ & $\begin{array}{c}\text { Baw } \\
\text { ah }\end{array}$ & Atas & $\begin{array}{c}\text { Baw } \\
\text { ah }\end{array}$ & Atas & $\begin{array}{c}\text { Bawa } \\
\mathrm{h}\end{array}$ & Atas \\
\hline 10 & 100 & 100 & 100 & 100 & 100 & 100 & 100 & 100 \\
\hline 4.8 & 90 & 100 & 90 & 100 & 90 & 100 & 95 & 100 \\
\hline 2.4 & 60 & 95 & 75 & 100 & 85 & 100 & 95 & 100 \\
\hline 1.2 & 30 & 70 & 55 & 100 & 75 & 100 & 90 & 100 \\
\hline 0.6 & 15 & 34 & 35 & 59 & 60 & 79 & 80 & 100 \\
\hline 0.3 & 5 & 20 & 8 & 30 & 12 & 40 & 15 & 50 \\
\hline 0.15 & 0 & 10 & 0 & 10 & 0 & 10 & 0 & 15 \\
\hline
\end{tabular}

Sumber : SNI 03-2834-2000

2. Agregat kasar berupa kerikil sebagai hasil disintegrasi 'alami' dari batuan atau berupa batu pecah yang diperoleh dari industri pemecah batu dan mempunyai ukuran butiran antara $5 \mathrm{~mm}$ sampai $40 \mathrm{~mm}^{[2]}$.

Tabel 2. Syarat Gradasi Agregat Kasar ${ }^{[3]}$

\begin{tabular}{|c|c|c|c|}
\hline \multirow{2}{*}{$\begin{array}{c}\text { Ukuran } \\
\text { Lubang } \\
\text { Ayakan } \\
(\mathrm{mm})\end{array}$} & \multicolumn{3}{|c|}{$\begin{array}{c}\text { Persentase Berat Bagian Yang Lewat } \\
\text { Ayakan }\end{array}$} \\
\cline { 2 - 4 } & \multicolumn{2}{|c|}{ Ukuran Nominal Agregat (mm) } \\
\cline { 2 - 4 } & 40 & 20 & 10 \\
\hline 38,1 & $95-100$ & 100 & - \\
\hline 19,0 & $37-70$ & $95-100$ & 100 \\
\hline 9,52 & $10-40$ & $30-60$ & $50-85$ \\
\hline 4,76 & $0-5$ & $0-10$ & $0-10$ \\
\hline
\end{tabular}

Sumber : SNI 03-2834-2000

\section{Abu Terbang (Fly Ash) dan bottom ash}

Fly ash dan bottom ash adalah limbah dari sisa pembakaran batubara. Pada waktu pembakaran batubara pada suatu pembangkit tenaga batubara, akan menghasilkan sisa pembakaran yang terdiri dari $80 \%$ berupa fly ash dan sisanya $20 \%$ berupa bottom ash. Bottom ash mempunyai karakteristik fisik berwarna abu-abu gelap, berbentuk butiran, berporos, mempunyai ukuran butiran antara pasir hingga kerikil. Menurut ACI Committee 226 dijelaskan bahwa, fly-ash mempunyai butiran yang cukup halus, yaitu lolos ayakan N0. 325 (45 milimikron) $5-27 \%$, dengan spesific gravity antara 2,15-2,8 dan berwarna abu-abu kehitaman. Sifat proses pozzolanic dari fly-ash mirip dengan bahan pozzolan lainnya.

\section{Silica Fume}

Menurut standar Spesification for Silica Fume for Use in Hydaulic Cemen Concrete and Mortar (ASTM C618-86) ${ }^{[4]}$, silica fume merupakan bahan yang mengandung $\mathrm{SiO}_{2}$ lebih besar dari $85 \%$ dan merupakan bahan yang sangat halus berbentuk bulat dan berdiameter 1/100 diameter semen. Menurut Subakti, silica fume mempunyai peranan penting terhadap pengaruh sifat kimia dan mekanik beton. Ditinjau dari sifat kimianya, secara geometris silica fume mengisi rongga-rongga diantara bahan semen, dan mengakibatkan diameter pori mengecil serta total volume pori juga berkurang. Sedangkan dari sifat mekaniknya, silica fume memiliki reaksi yang bersifat pozzolan yang bereaksi terhadap batu kapur yang dilepas semen. Karena kandungan $\mathrm{SiO}_{2}$ yang cukup tinggi, hidrasi air dan semen akan menghasilkan $\mathrm{Ca}(\mathrm{OH})_{2}$ yaitu bahan yang mudah larut dalam air. Kalsium hidroksida $\mathrm{Ca}(\mathrm{OH})_{2}$ ini bereaksi dengan silica oksida $\left(\mathrm{SiO}_{2}\right)$ membentuk kalsium silikat hidrat, dimana C-S-H ini mempengaruhi kekerasan beton.

\section{Superplasticizer}

Superplasticizer dapat memperbaiki workability namun tidak terpengaruh besar dalam meningkatkan kuat tekan beton untuk faktor air semen yang diberikan. Namun kegunaan superplasticizer untuk beton mutu tinggi secara umum sangat berhubungan dengan pengurangan jumlah air dalam campuran beton. Pengurangan ini tergantung dari kandungan air yang digunakan, dosis dan tipe dari superplasticizer yang dipakai.

\section{Kuat Tekan Beton}

Nilai kuat tekan beton didapat dari pengujian standar dengan benda uji yang lazim digunakan berbentuk silinder. Dimensi benda uji standar adalah tinggi $300 \mathrm{~mm}$, diameter $150 \mathrm{~mm}$ pada umur 28 hari. Tata cara pengujian yang umumnya dipakai adalah standar ASTM C39-86. 


\section{Slump Test}

Nilai slump digunakan untuk pengukuran terhadap tingkat kelecekan suatu adukan beton, yang berpengaruh pada tingkat pengerjaan beton (workability). Slump pada dasarnya salah satu pengetesan sederhana untuk mengetahui workability beton segar sebelum dterima dan diaplikasikan dalam pekerjaan pengecoran.

Tabel 3. Kategori Nilai Slump Test

\begin{tabular}{|l|c|c|}
\hline Keterangan & $\begin{array}{c}\text { Nilai Slump } \\
(\mathbf{m m})\end{array}$ & $\begin{array}{c}\text { Air Yang } \\
\text { Diperlukan } \\
(\mathbf{\%})\end{array}$ \\
\hline Sangat Kering & - & 78 \\
\hline Sangat Keras & - & 83 \\
\hline Keras & $0-30$ & 88 \\
\hline Agak Plastis & $30-80$ & 92 \\
\hline Plastis & $80-130$ & 100 \\
\hline Encer & $130-180$ & 106 \\
\hline
\end{tabular}

Sumber : SNI $2847: 2013$

\section{Suhu Beton Pada Saat Pengecoran}

Thermometer mampu mengukur suhu beton segar antara 0 sampai $50^{\circ} \mathrm{C}$ dengan ketelitian $\pm 0,5^{\circ} \mathrm{C}$, dengan kedalaman pencelupannya yaitu $75 \mathrm{~mm}^{[5]}$. Pengikatan semen berlangsung dengan baik pada suhu $35^{\circ} \mathrm{C}$ dan berjalan dengan lambat pada suhu di bawah $15^{\circ} \mathrm{C}$.

\section{Setting Time (Berdasarkan ASTM C 1117 - 89)}

Waktu ikat (setting time) adalah waktu yang dibutuhan melakukan proses hidrolis dimana hingga satu waktu tertentu, beton tersebut sudah memiliki kekuatan tertentu pula. ASTM menetapkan bahwa waktu yang dibutuhkan beton agar memiliki kuat desak 500 Psi disebut sebagai Initial Setting Time. Sedangkan waktu yang dibutuhkan pasta beton memiliki kekuatan desak 4000 psi disebut sebagai Final Setting Time.

\section{Perencanaan Campuran Beton (Mix Design)}

Mix design merupakan rencana campuran adukan beton untuk mengetahui jumlah kebetuhan material sesuai dengan kekuatan rencana. Mix design yang dibuat dalam penelitian ini berdasarkan "Tata Cara Pembuatan Beton Normal" mengacu pada SNI 03$2834-2000^{[6]}$.

\section{Metodologi Penelitian}

Secara garis besar tahapan kegiatan penelitian dapat di kelompokkan menjadi tiga tahapan yaitu : tahap persiapan, tahap pelaksanaan pengujian laboratorium, tahap analisis data dan pembuatan laporan hasil. Penjelasan langkah-langkah penelitian sebagai berikut :

\section{A. Tahap Persiapan \\ 1. Studi Literatur}

Pada tahap ini dilakukan pencarian referensireferensi penelitian yang berhubungan dengan penelitian yang akan dilaksanakan.

2. Persiapan Alat dan Material

Mengajukan permohonan melakukan pembuatan dan pengujian beton di PT. Waskita Beton Precast.

\section{B. Tahap Pelaksanaan}

1. Pembuatan Sampel Penelitian

Pembuatan sampel untuk penelitian sebanyak 99 sampel dengan masing-masing variasi 9 sampel untuk variasi campuran kadar abu terbang (fly ash) dan bottom ash sebesar 0\%, 5\%, 10\%, 15\%, $20 \%$ dan $25 \%$ dari berat semen, yang dikombinasi dengan variasi silica fume $0 \%, 2 \%$, $4 \%, 6 \%, 8 \%, 10 \%$ dari berat semen yang sudah dikurangi dengan berat semen fly ash dan bottom ash, dan ditambah dengan superplasticizer sebesar $2 \%$ dari kebutuhan air.

2. Pelaksanaan Pengujian dan Pengumpulan Data Tahap ini merupakan tahap melakukan pengujian tiap sampel yang sudah dibuat yang kemudian dicatat hasilnya. Dengan pengujian pada umur 7 hari, 14 hari dan 28 hari

\section{Tahap Analisa}

Setelah didapatkan data hasil pengujian kemudian dilakukan analisa dan pembahasan serta membandingkan hasil fly ash dan bottom ash dengan bahan admixture terhadap slump test, suhu beton segar, kuat tekan beton, serta setting timenya.

\section{Analisis Dan Pembahasan}

\section{Pengujian Agregat Halus/Pasir}

a. Analisa Gradasi Pasir

Berdasarkan hasil dari pengujian bahwa pasir Bangka mempunyai modulus kehalusan pasir sebesar 2,482 \% termasuk ketagori pasir halus dan memenuhi syarat yang ditetapkan dalam SNI 03-6820-2002 $2^{7}$ yakni modulus kehausan pasir sebesar $1,50 \%-3,80 \%$.

Tabel 4. Hasil Pengujian Analisis Gradasi Pasir

\begin{tabular}{|c|c|c|c|c|}
\hline \multicolumn{2}{|c|}{$\begin{array}{l}\text { Lubang } \\
\text { Ayakan }\end{array}$} & \multirow{2}{*}{$\begin{array}{c}\text { Berat } \\
\text { Tertinggal } \\
\text { (gram) }\end{array}$} & \multirow[t]{2}{*}{$\begin{array}{c}\% \\
\text { Tertinggal }\end{array}$} & \multirow[t]{2}{*}{$\begin{array}{c}\% \\
\text { komulatif }\end{array}$} \\
\hline $\mathrm{mm}$ & No. & & & \\
\hline 9,50 & $3 / 8^{\prime \prime}$ & 0 & 0 & 100 \\
\hline 4,75 & 4 & 0,8 & 0,09 & 99,91 \\
\hline 2,36 & 8 & 70,2 & 7,48 & 92,52 \\
\hline 1,18 & 16 & 188,8 & 20,13 & 79,87 \\
\hline 0,60 & 30 & 442,4 & 47,16 & 52,84 \\
\hline 0,30 & 50 & 704,8 & 75,14 & 24,86 \\
\hline 0,15 & 100 & 928 & 98,17 & 1,83 \\
\hline Pan & & 938 & 100 & 0 \\
\hline \multicolumn{4}{|c|}{$\begin{array}{l}\text { FM : } \\
\begin{array}{l}\text { Modulus Kehalusan Pasir } \\
\text { komulatif yang tertinggal }\end{array}=\underline{\text { Jumlah \% }} \\
100 \%\end{array}$} & $2,482 \%$ \\
\hline
\end{tabular}


Batas gradasi pasir dapat dilihat pada Tabel 5, dimana hasil analisa gradasi pasir Bangka termasuk zona II yaitu masuk kategori pasir agak kasar, seperti terlihat pada Grafik 1.

Tabel 5. Batas dan Hasil Pengujian Gradasi Pasir

\begin{tabular}{|c|c|c|c|c|c|}
\hline \multirow{2}{*}{$\begin{array}{c}\text { Lubang } \\
\begin{array}{c}\text { Ayakan } \\
(\mathbf{m m})\end{array}\end{array}$} & $\begin{array}{c}\text { Kasar } \\
\text { (Zona } \\
\text { I) }\end{array}$ & $\begin{array}{c}\text { Agak } \\
\text { Kasar } \\
\text { (Zona } \\
\text { II) }\end{array}$ & $\begin{array}{c}\text { Agak } \\
\text { Halus } \\
\text { (Zona } \\
\text { III) }\end{array}$ & $\begin{array}{c}\text { Halus } \\
\text { (Zona } \\
\text { IV) }\end{array}$ & $\begin{array}{c}\text { Pasir } \\
\text { Bangka }\end{array}$ \\
\hline 9,6 & 100 & $\mathbf{1 0 0}$ & 100 & 100 & $\mathbf{1 0 0}$ \\
\hline 4,8 & $\begin{array}{c}90- \\
100\end{array}$ & $\begin{array}{c}\mathbf{9 0}- \\
\mathbf{1 0 0}\end{array}$ & $\begin{array}{c}90- \\
100\end{array}$ & $\begin{array}{c}95- \\
100\end{array}$ & $\mathbf{9 9 , 9 1}$ \\
\hline 2,4 & $\begin{array}{c}60- \\
95\end{array}$ & $\begin{array}{c}\mathbf{7 5}- \\
\mathbf{1 0 0}\end{array}$ & $\begin{array}{c}85- \\
100\end{array}$ & $\begin{array}{c}95- \\
100\end{array}$ & $\mathbf{9 2 , 5 2}$ \\
\hline 1,2 & $30-$ & $\mathbf{5 5}-$ & $75-$ & $90-$ & $\mathbf{7 9 , 8 7}$ \\
$\mathbf{9 0}$ & 75 & 100 & 100 & $\begin{array}{c}80- \\
100\end{array}$ & $\mathbf{5 2 , 8 4}$ \\
\hline 0,6 & $\begin{array}{c}\mathbf{9 0}- \\
34\end{array}$ & $\begin{array}{c}\mathbf{3 3}- \\
\mathbf{5 9}\end{array}$ & $60-79$ & $\mathbf{2 4 , 8 6}$ \\
\hline 0,3 & $5-20$ & $\mathbf{8}-\mathbf{3 0}$ & $12-40$ & $\begin{array}{c}15- \\
100\end{array}$ & \\
\hline 0,15 & $0-10$ & $\mathbf{0}-\mathbf{1 0}$ & $0-10$ & $0-$ & $\mathbf{1 , 8 3}$ \\
\hline
\end{tabular}

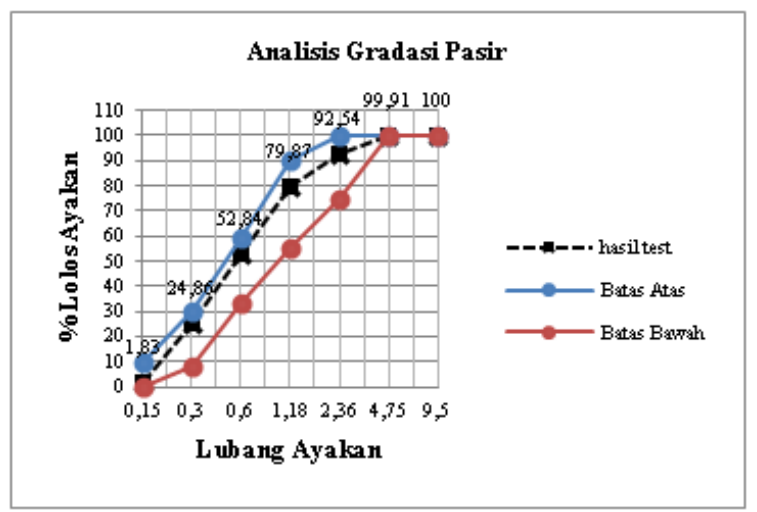

Gambar 1. Grafik Pengujian Analisis Gradasi Pasir

b. Kandungan Lumpur Dalam Pasir

Berdasarkan hasil pengujian tentang kandungan lumpur dalam pasir, didapatkan kandungan lumpur pada pasir Bangka rata-rata sebesar 2,980\%. Kandungan lumpur dalam pasir ini memenuhi syarat yang ditetapkan dalam menurut SNI 03-6820-2002 ${ }^{7}$ yakni kandungan lumpur dalam pasir sebanyak $5 \%$.

Tabel 6. Hasil Data Kandungan Lumpur Dalam Pasir

\begin{tabular}{|l|l|c|c|}
\hline No. & Keterangan & $\begin{array}{c}\text { Sample } \\
\text { I }\end{array}$ & $\begin{array}{c}\text { Sample } \\
\text { II }\end{array}$ \\
\hline A & Berat pasir (S) & $500 \mathrm{gr}$ & $500 \mathrm{gr}$ \\
\hline B & $\begin{array}{l}\text { Berat pasir setelah } \\
\text { dikeringkan (A) }\end{array}$ & $481,6 \mathrm{gr}$ & $488,6 \mathrm{gr}$ \\
\hline C & $\begin{array}{l}\text { Kadar lumpur } \\
\text { pasir }\left(\frac{S-A}{S} \times 100 \%\right)\end{array}$ & $3,680 \%$ & $2,980 \%$ \\
\hline \multicolumn{2}{|l|}{ Rata - rata kadar lumpur pasir } & \multicolumn{2}{|c|}{$2,980 \%$} \\
\hline
\end{tabular}

\section{c. Kadar Air Pasir}

Berdasarkan hasil pemeriksaan kadar air pasir diperoleh hasil dalam pengujian ini sebesar 9,294\%.
Tabel 7. Hasil Data Kadar Air Pasir

\begin{tabular}{|c|l|ll|}
\hline No & \multicolumn{1}{|c|}{ Keterangan } & \multicolumn{2}{|c|}{ Hasil } \\
\hline 1 & Berat wadah $\left(\mathrm{W}_{1}\right)$ & 215 & $\mathrm{gr}$ \\
\hline 2 & Berat benda uji + wadah $\left(\mathrm{W}_{2}\right)$ & 1240,4 & $\mathrm{gr}$ \\
\hline 3 & Berat benda uji $\left(\mathrm{W}_{3}\right)$ & 1025,4 & $\mathrm{gr}$ \\
\hline 4 & $\begin{array}{l}\text { Berat benda uji setelah di oven }+ \\
\text { wadah }\left(\mathrm{W}_{4}\right)\end{array}$ & $1153,2 \mathrm{gr}$ \\
\hline 5 & $\begin{array}{l}\text { Berat benda uji setelah di oven } \\
\left(\mathrm{W}_{5}\right)\end{array}$ & $938,2 \mathrm{gr}$ \\
\hline 6 & $\%$ Kadar air pasir & $9,294 \quad \%$ \\
\hline
\end{tabular}

d. Kandungan Organis Dalam Pasir

Berdasarkan hasil pengujian kandungan organis dalam pasir, hasil yang didapatkan pada pembacaan picmen colour adalah warna kuning (standar), mengindikasikan kandungan organik dalam pasir sangat sedikit.

Tabel 8. Hasil Data Kandungan Organis Dalam Pasir

\begin{tabular}{|c|l|c|}
\hline \multirow{2}{*}{$\begin{array}{c}\text { Warna Pasir Setelah di } \\
\text { Tambah Larutan NaoH }\end{array}$} & \multicolumn{2}{|c|}{ Form Warna } \\
\hline \multirow{3}{*}{$\begin{array}{c}\text { Bening / Sama Dengan / } \\
\text { Lebih Gelap dari }\end{array}$} & 1. Jernih & \\
\cline { 2 - 3 } & 2. Jernih Kuning & \\
\cline { 2 - 3 } & $\begin{array}{l}\text { 3. Kuning } \\
\text { (Standar) }\end{array}$ & $\mathrm{v}$ \\
\cline { 2 - 3 } & 4. Coklat & \\
\cline { 2 - 3 } & 5. Coklat Gelap & \\
\hline
\end{tabular}

e. Berat Jenis Pasir dan Penyerapan Air

Berdasarkan hasil pengujian berat jenis pasir dan penyerapan air menunjukkan bahwa rata-rata berat jenis kering pasir Bangkayang didapatkan dalam pengujian sebesar 2,508. Untuk rata-rata berat jenis dalam kondisi SSD (Saturated Surface Dry) yang didapatkan sebesar 2,584. Sedangkan, rata-rata hasil pengujian penyerapan air sebesar 3,077 \% .

Tabel 9. Hasil Data Berat Jenis Pasir dan Penyerapan Air

\begin{tabular}{|c|c|c|c|}
\hline No. & Keterangan & $\begin{array}{l}\text { Sample } \\
\text { I }\end{array}$ & $\begin{array}{l}\text { Sample } \\
\text { II }\end{array}$ \\
\hline $\mathrm{A}$ & Berat pasir $(\mathrm{S})$ & $500 \mathrm{gr}$ & $500 \mathrm{gr}$ \\
\hline B & $\begin{array}{l}\text { Berat pasir setelah } \\
\text { dikeringkan }(\mathrm{A})\end{array}$ & $481,6 \mathrm{gr}$ & $\begin{array}{c}488,6 \\
\mathrm{gr}\end{array}$ \\
\hline $\mathrm{C}$ & Berat air + piknometer (B) & $741,4 \mathrm{gr}$ & $\begin{array}{c}741,4 \\
\mathrm{gr}\end{array}$ \\
\hline $\mathrm{D}$ & $\begin{array}{l}\text { Berat piknometer }+500 \mathrm{gr} \\
\text { pasir }+ \text { air }(\mathrm{C})\end{array}$ & $\begin{array}{c}1045,2 \\
\text { gr }\end{array}$ & $\begin{array}{c}1050,6 \\
\mathrm{gr}\end{array}$ \\
\hline $\mathrm{E}$ & $\begin{array}{l}\text { Berat jenis kering }= \\
\left(\frac{A}{(B+S)-c}\right)\end{array}$ & 2,455 & 2,561 \\
\hline $\mathrm{F}$ & $\begin{array}{l}\text { Saturated Surface Dry } \\
(\mathrm{SSD})=\left(\frac{S}{(B+S)-C}\right)\end{array}$ & 2,548 & 2,621 \\
\hline G & $\begin{array}{l}\% \text { Penyerapan }= \\
\left(\frac{S-A}{A} \times 100 \%\right)\end{array}$ & $2,709 \%$ & $2,333 \%$ \\
\hline $\mathrm{H}$ & $\begin{array}{l}\text { Rata - rataberat jenis } \\
\text { kering }\end{array}$ & \multicolumn{2}{|c|}{2,508} \\
\hline $\mathrm{I}$ & $\begin{array}{l}\text { Rata - rata Saturated } \\
\text { Surface Dry }(\mathrm{SSD})\end{array}$ & \multicolumn{2}{|c|}{2,584} \\
\hline $\mathrm{J}$ & Rata - rata \% penyerapan & \multicolumn{2}{|c|}{$3,077 \%$} \\
\hline
\end{tabular}




\section{Hasil Pengujian Agregat Kasar (Kerikil)}

a. Analisis Gradasi Kerikil

Berdasarkan hasil dari pengujian analisis gradasi kerikil Rumpin, Bogor menunjukkan bahwa hasil untuk modulus kehalusan yang didapat sebesar 5,327 $\%$. Nilai modulus kehalusan ini, memenuhi syarat menurut SNI 03-2867-2002 $2^{7}$ yaitu modulus kehalusan kerikil $6 \%-7,1 \%$.

Tabel 10. Hasil Pengujian Analisis Gradasi Kerikil

\begin{tabular}{|c|c|c|c|}
\hline $\begin{array}{c}\text { Lubang } \\
\text { Ayakan } \\
(\mathbf{m m})\end{array}$ & $\begin{array}{c}\text { Berat } \\
\text { Tertinggal } \\
(\mathbf{g r})\end{array}$ & $\begin{array}{c}\text { Persen } \\
\text { Komulatif } \\
(\boldsymbol{\%})\end{array}$ & $\begin{array}{c}\text { Persen } \\
\text { Komulatif } \\
\text { Lewat } \\
\text { Ayakan }(\%)\end{array}$ \\
\hline 37,5 & 0 & 0 & 100 \\
\hline 25,0 & 22,6 & 2,12 & 97,88 \\
\hline 19,0 & 518,2 & 48,65 & 51,35 \\
\hline 12,5 & 928,4 & 87,17 & 12,83 \\
\hline 9,5 & 1023,2 & 96,07 & 3,93 \\
\hline 4,75 & 1052,6 & 98,83 & 1,17 \\
\hline 2,36 & 1053 & 99,86 & 1,14 \\
\hline PAN & 1065,1 & 100 & 0 \\
\hline $\begin{array}{l}\text { FM : Modulus Kehalusan Kerikil } \\
\text { Jumlah \% komulatif yang tertinggal }\end{array}$ & $5,327 \%$ \\
\hline \multicolumn{4}{l}{$100 \%$} \\
\hline
\end{tabular}

Tabel 11. Syarat Batas dan Hasil Gradasi Kerikil

\begin{tabular}{|c|c|c|c|c|}
\hline \multirow{3}{*}{$\begin{array}{c}\text { Ukuran } \\
\text { Lubang } \\
\text { Ayakan } \\
(\mathrm{mm})\end{array}$} & \multicolumn{4}{|c|}{$\begin{array}{c}\text { Persentase Berat Bagian Yang Lewat } \\
\text { Ayakan }\end{array}$} \\
\hline & \multicolumn{3}{|c|}{$\begin{array}{l}\text { Ukuran Nominal Agregat } \\
\qquad(\mathrm{mm})\end{array}$} & $\begin{array}{c}\text { Hasil } \\
\text { Gradasi } \\
\text { Kerikil }\end{array}$ \\
\hline & 40 & 20 & 10 & 40 \\
\hline 38,1 & $95-100$ & 100 & - & 100 \\
\hline 19,0 & $37-70$ & $95-100$ & 100 & 51,35 \\
\hline 9,52 & $10-40$ & $30-60$ & $50-85$ & 12,83 \\
\hline 4,76 & 0 - 5 & $0-10$ & $0-10$ & 1,17 \\
\hline
\end{tabular}

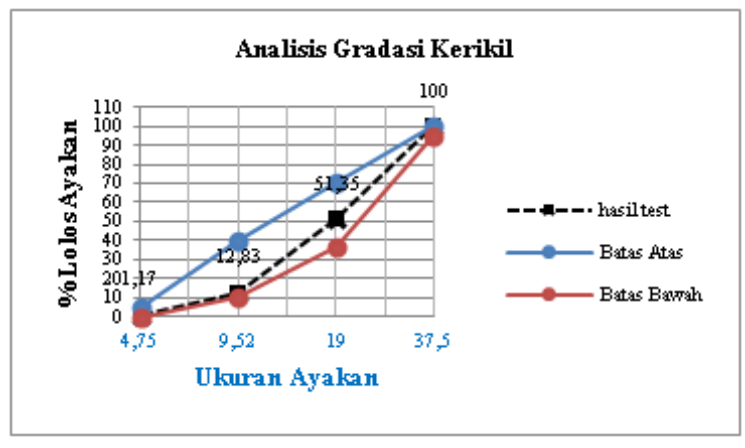

Gambar 2. Grafik Pengujian Analisis Gradasi Kerikil

b. Kandungan Lumpur Dalam Kerikil

Berdasarkan hasil pengujian tentang kandungan lumpur dalam kerikil, didapatkan kandungan lumpur pada kerikil Rumpin, Bogor rata-rata sebesar 1,994 $\%$. Hasil ini berarti menunjukkan nilai kadar lumpur lebih dari $1 \%$ maka kerikil harus dicuci terlebih dahulu sebelum digunakan.
Tabel 12. Hasil Data Kandungan Lumpur Dalam Kerikil

\begin{tabular}{|c|l|c|c|}
\hline No. & \multicolumn{1}{|c|}{ Keterangan } & $\begin{array}{c}\text { Sample } \\
\text { I }\end{array}$ & $\begin{array}{c}\text { Sample } \\
\text { II }\end{array}$ \\
\hline A & $\begin{array}{l}\text { Berat kerikil setelah } \\
\text { dikeringkan }(A)\end{array}$ & $\begin{array}{c}1465.8 \\
\mathrm{gr}\end{array}$ & 1474.4 \\
\hline B & Berat kerikil (B) & $1500 \mathrm{gr}$ & $1500 \mathrm{gr}$ \\
\hline C & $\begin{array}{l}\text { Kadar lumpur } \\
\text { kerikil }\left(\frac{B-A}{B} \times 100 \%\right)\end{array}$ & $2,280 \%$ & $1,707 \%$ \\
\hline \multicolumn{2}{|l|}{ Rata-rata kadar lumpur kerikil } & $1,994 \%$ \\
\hline
\end{tabular}

c. Kadar Air Kerikil

Berdasarkan hasil pemeriksaan kadar air kerikildiperoleh hasil dalam pengujian ini sebesar $2,375 \%$. Hasil ini memenuhi syarat berdasarkan SNI 03-2461-2002 spesifikasi kadar air kerikil yaitu 3\%.

Tabel 13. Hasil Data Kadar Air Keriki

\begin{tabular}{|c|l|ll|}
\hline No & \multicolumn{1}{|c|}{ Keterangan } & \multicolumn{2}{|c|}{ Hasil } \\
\hline 1 & Berat wadah $\left(\mathrm{W}_{1}\right)$ & 215 & $\mathrm{gr}$ \\
\hline 2 & Berat benda uji + wadah $\left(\mathrm{W}_{2}\right)$ & 1715 & $\mathrm{gr}$ \\
\hline 3 & Berat benda uji $\left(\mathrm{W}_{3}\right)$ & $1500 \quad \mathrm{gr}$ \\
\hline 4 & $\begin{array}{l}\text { Berat benda uji setelah di oven } \\
+ \text { wadah }\left(\mathrm{W}_{4}\right)\end{array}$ & $1680,2 \mathrm{gr}$ \\
\hline 5 & $\begin{array}{l}\text { Berat benda uji setelah di oven } \\
\left(\mathrm{W}_{5}\right)\end{array}$ & $1462,5 \mathrm{gr}$ \\
\hline 6 & $\%$ Kadar air kerikil & $2,375 \quad \%$ \\
\hline
\end{tabular}

d. Berat Jenis Kerikildan Penyerapan Air

Berdasarkan hasil pengujian berat kerikil dan penyerapan air menunjukkan bahwa rata-rata berat jenis keringkerikil adalah 2,737 dan untuk rata-rata berat jenis kondisi Saturated Surface Dry (SSD) adalah 2,792 dan penyerapan air sebesar 2,035\%.

Tabel 14. Hasil Pengujian Berat Jenis Kerikil dan Penyerapan Air

\begin{tabular}{|c|l|c|c|}
\hline No. & \multicolumn{1}{|c|}{ Keterangan } & Sample I & $\begin{array}{c}\text { Sample } \\
\text { II }\end{array}$ \\
\hline A & Berat agregat kasar & $1500 \mathrm{gr}$ & $1500 \mathrm{gr}$ \\
\hline B & $\begin{array}{l}\text { Berat agregat kasar } \\
\text { setelah dikeringkan }\end{array}$ & $1465.8 \mathrm{gr}$ & 1474.4 \\
\hline C & $\begin{array}{l}\text { Berat agregat kasar } \\
\text { dalam air }\end{array}$ & $962.5 \mathrm{gr}$ & 963.1 \\
\hline D & $\begin{array}{l}\text { Berat jenis agregat } \\
\text { kasar }\left(\frac{B}{A-C}\right)\end{array}$ & 2,727 & 2,746 \\
\hline E & $\begin{array}{l}\text { Saturated Surface Dry } \\
(\text { SSD })\left(\frac{A}{A-C}\right)\end{array}$ & 2,791 & 2,794 \\
\hline F & $\begin{array}{l}\% \text { Penyerapan } \\
\left(\frac{A-B}{B} x 100 \%\right)\end{array}$ & $2,333 \%$ & $1,736 \%$ \\
\hline G & $\begin{array}{l}\text { Rata }- \text { rataberat jenis } \\
\text { kering }\end{array}$ & 2,737 \\
\hline H & $\begin{array}{l}\text { Rata - rata Saturated } \\
\text { Surface Dry }(\text { SSD })\end{array}$ & 2,792 \\
\hline I & $\begin{array}{l}\text { Rata }- \text { rata } \% \\
\text { penyerapan }\end{array}$ & $2,035 \%$ \\
\hline
\end{tabular}

\section{Jumlah Kebutuhan Bahan Material}

Pada penelitian ini sampel beton yang akan dibuat ada 9 variasi dengan total jumlah sebanyak 54 silinder. Proporsi bahan material beton dengan mix 
design menggunakan metode SNI 03-2834-2000 3 pada tabel berikut :

Tabel 15. Proporsi Campuran Variasi Abu Terbang (Fly Ash) dan Bottom ash dengan Tambahan Variasi Silicafume dan Superplasticizer Untuk 9 Silinder

\begin{tabular}{|c|c|c|c|c|c|c|c|c|}
\hline \multirow[b]{2}{*}{ No } & \multirow[b]{2}{*}{ Sampel } & \multicolumn{7}{|c|}{ Komposisi Material } \\
\hline & & $\begin{array}{c}\text { Semen } \\
(\mathrm{kg})\end{array}$ & $\begin{array}{l}\text { Ash } \\
\text { (kg) }\end{array}$ & $\underset{(\mathbf{k g})}{\text { Kerikil }}$ & $\begin{array}{c}\text { Pasir } \\
(\mathbf{k g})\end{array}$ & $\begin{array}{c}\text { Silica } \\
\text { fume } \\
(\mathrm{kg})\end{array}$ & $\underset{\text { Air }}{\text { Aiter) }}$ & $\begin{array}{c}\text { Superplas } \\
\text { ticizer } \\
2 \%(\mathrm{ml}) \\
\end{array}$ \\
\hline 1 & $\begin{array}{c}\text { FA 0\% } \\
\& \\
\text { SF 0\% }\end{array}$ & 21,335 & 0 & 49,941 & 30,609 & 0 & 8,321 & 0 \\
\hline 2 & $\begin{array}{c}\text { FA 5\% } \\
\& \\
\text { SF 2\% }\end{array}$ & 19,863 & 1,067 & 49,941 & 30,609 & 0,405 & 8,155 & 16600 \\
\hline 3 & $\begin{array}{c}\mathrm{FA} 10 \% \\
\& \\
\text { SF } 4 \%\end{array}$ & 18,433 & 2,134 & 49,941 & 30,609 & 0,768 & 8,155 & 16600 \\
\hline 4 & $\begin{array}{c}\text { FA } 15 \% \\
\& \\
\text { SF } 6 \%\end{array}$ & 17,047 & 3,200 & 49,941 & 30,609 & 1,088 & 8,155 & 16600 \\
\hline 5 & $\begin{array}{c}\text { FA 20\% } \\
\& \\
\text { SF 8\% }\end{array}$ & 15,703 & 4,627 & 49,941 & 30,609 & 1,365 & 8,155 & 16600 \\
\hline 6 & $\begin{array}{c}\text { FA 25\% } \\
\& \\
\text { SF } 10 \%\end{array}$ & 14,401 & 5,334 & 49,941 & 30,609 & 1,600 & 8,155 & 16600 \\
\hline
\end{tabular}

\section{Hasil Pengujian Suhu Saat Pengecoran}

Berdasarkan hasil pengujian suhu saat pengecoran bahwa campuran variasi tertentu abu terbang (fly ash) dan bottom ash dengan tambahan silica fume dan superplasticizer memiliki nilai suhu lebih tinggi satu derajat dari suhu beton normal.Karena, nilai suhu yang tinggi ini dipengaruhi dengan adanya bahan tambahan silica fume dan superplasticizer. Untuk nilai suhu yang semakin menurun dengan meningkatnya kadar abu terbang (fly ash) dan bottom ash, dikarenakan terjadinyareaksi pozzolan pada abu terbang (fly ash) dan bottom ash yang mempengaruhi penurunan suhu.

Tabel 16. Hasil Suhu Saat Pengecoran Variasi Abu Terbang (Fly Ash) dan Bottom Ash dengan Tambahan Variasi Silica Fume dan Superplasticizer

\begin{tabular}{|c|c|c|}
\hline Sample & $\begin{array}{c}\text { Fly Ash } \\
\text { Suhu Saat } \\
\text { Pengecoran } \\
\left({ }^{\mathbf{C})}\right.\end{array}$ & $\begin{array}{c}\text { Bottom Ash } \\
\text { Suhu Saat } \\
\text { Pengecoran } \\
\left({ }^{\mathbf{0}} \mathbf{C}\right)\end{array}$ \\
\hline $\begin{array}{c}\text { Normal (0\%) } \\
\text { SP 2 \% }\end{array}$ & 36 & 36 \\
\hline $\begin{array}{c}\text { FA 10\% +SF 4\%+ } \\
\text { SP 2\% }\end{array}$ & 37 & 37 \\
\hline $\begin{array}{c}\text { FA 15\% + SF 6\%+ } \\
\text { SP 2\% }\end{array}$ & 36 & 36 \\
\hline $\begin{array}{c}\text { FA 20\% + SF 8 \%+ } \\
\text { SP 2\% }\end{array}$ & 33 & 36 \\
\hline $\begin{array}{c}\text { FA 25 + SF 10 \%+ } \\
\text { SP 2\% }\end{array}$ & 33 & 34 \\
\hline
\end{tabular}

\section{Hasil Pengujian Nilai Slump Test}

Berdasarkan hasil penelitian dan pembacaan di Tabel 17 dinyatakan bahwa nilai slump test yang didapatkan sesuai dengan nilai dari tabel slump test (Tabel 3) dimana nilai slump test yang ditentukan berkisar $80 \mathrm{~mm}-130 \mathrm{~mm}$ termasuk slump plastis.

Pada abu terbang (fly ash) dapat dilihat untuk nilai slump test terendah pada variasi FA 5\%,SF 2\%,
SP $2 \%$ yaitu $11 \mathrm{~cm}$. Dan nilai slump tertinggi pada variasi FA 25\%, SF 10\%, SP 2\% yaitu $13 \mathrm{~cm}$.

Pada bottom ash, nilai slump test yang terendah terdapat pada variasi BA 5\%, SF $2 \%$, SP $2 \%$ yaitu $11,5 \mathrm{~cm}$. Dan nilai slump tertinggi pada pada variasi BA $25 \%$, SF $10 \%$, SP $2 \%$ terdapat pada nilai $14 \mathrm{~cm}$.

Tabel 17. Hasil Slump Test Variasi Abu Terbang (Fly Ash) dan Bottom Ash dengan Tambahan Variasi Silica Fume dan Superplasticizer

\begin{tabular}{|c|c|c|}
\hline & Fly Ash & Bottom Ash \\
\hline Sample & $\begin{array}{c}\text { Nilai } \\
\text { slump } \\
\text { beton } \\
\text { (Cm) }\end{array}$ & $\begin{array}{l}\text { Nilai slump } \\
\text { beton (Cm) }\end{array}$ \\
\hline Normal $(0 \%)$ & 12 & 12 \\
\hline $\begin{array}{c}\mathrm{FA} 5 \%+\mathrm{SF} 2 \%+ \\
\text { SP } 2 \%\end{array}$ & 11 & 11,5 \\
\hline $\begin{array}{c}\mathrm{FA} 10 \%+\mathrm{SF} 4 \%+ \\
\mathrm{SP} 2 \%\end{array}$ & 12 & 12 \\
\hline $\begin{array}{c}\text { FA } 15 \%+\text { SF } 6 \%+ \\
\text { SP } 2 \%\end{array}$ & 11 & 12 \\
\hline $\begin{array}{c}\text { FA } 25 \%+\text { SF } 8 \%+ \\
\text { SP } 2 \%\end{array}$ & 11,5 & 13 \\
\hline $\begin{array}{c}\text { FA } 25 \%+\text { SF } 10 \%+ \\
\text { SP } 2 \%\end{array}$ & 13 & 14 \\
\hline
\end{tabular}

\section{Hasil Pengujian Kuat Tekan Beton}

a. Dari pembacaan Tabel 18 dan Gambar 3 dapat dilihat bahwa nilai kuat tekan rata-rata beton yang tertinggi pada umur 28 hari diperoleh campuran beton dengan variasi FA $10 \%+$ SF $4 \%$ + SP $2 \%$ yaitu 56,16 MPa. Untuk variasi FA $20 \%$ + SF $8 \%+$ SP $2 \%$ dan FA $25 \%+$ SF $10 \%+$ SP $2 \%$ memiliki kuat tekan terendah yaitu 41,61 MPa dan 41,42 MPa, dimana hasil kuat tekan ini tidak masuk dalam kuat tekan yang disyarakatkan (f'c) sebesar 41,7 MPa.

Tabel 18. Hasil Kuat Tekan Semua Variasi Abu Terbang (Fly Ash) dengan Tambahan Variasi Silica Fume dan Superplasticizer

\begin{tabular}{|c|c|c|c|c|c|c|}
\hline \multirow[b]{2}{*}{ Hari } & \multicolumn{6}{|c|}{ Kuat Tekan Beton (MPa) } \\
\hline & $\begin{array}{l}\text { Beton } \\
\text { Normal } \\
(0 \%)\end{array}$ & $\begin{array}{c}\text { Beton } \\
\text { Variasi } \\
\text { FA 5\% } \\
+ \text { SF } \\
2 \%+ \\
\text { SP 2\% }\end{array}$ & $\begin{array}{c}\text { Beton } \\
\text { Variasi } \\
\text { FA } \\
10 \%+ \\
\text { SF } 4 \% \\
+ \text { SP } \\
2 \%\end{array}$ & $\begin{array}{c}\text { Beton } \\
\text { Variasi } \\
\text { FA } \\
15 \% \\
+ \text { SF } \\
6 \% \\
+ \text { SP } \\
2 \%\end{array}$ & $\begin{array}{c}\text { Beton } \\
\text { Variasi } \\
\text { FA } \\
20 \%+ \\
\text { SF } 8 \% \\
+ \text { SP } \\
2 \%\end{array}$ & $\begin{array}{c}\text { Beton } \\
\text { Variasi } \\
\text { FA } \\
25 \% \\
+ \text { SF } \\
10 \%+ \\
\text { SP 2\% }\end{array}$ \\
\hline 7 & 31,04 & 37,56 & 39,63 & 36,23 & 34,44 & 30,48 \\
\hline 14 & 35,10 & 42,46 & 45,67 & 39,54 & 37,74 & 34,16 \\
\hline 28 & 41,89 & 54,73 & 56,16 & 49,54 & 41,61 & 41,42 \\
\hline
\end{tabular}




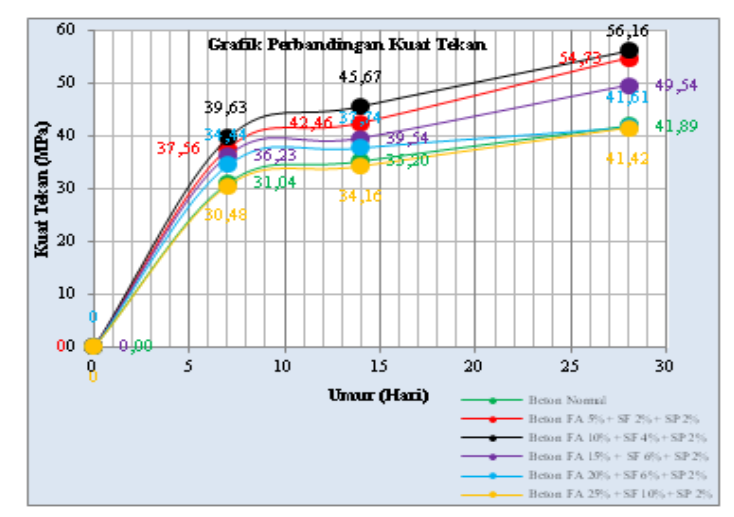

Gambar 3. Grafik Perbandingan Kuat Tekan Semua Variasi Abu Terbang (Fly Ash) dengan Tambahan Variasi Silica Fume dan Superplasticizer

b. Dari pembacaan Tabel 18 dan Gambar 4 dapat dilihat bahwa nilai kuat tekan rata-rata beton yang tertinggi pada umur 28 hari diperoleh campuran beton dengan variasi BA 5\% + SF $2 \%$ + SP 2\% yaitu 49,82 MPa. Untuk kuat tekan beton variasi BA $20 \%+$ SF $8 \%+$ SP $2 \%$ dan BA $25 \%+\mathrm{SF} 10 \%+\mathrm{SP} 2 \%$ mempunyai nilai kuat tekan terendah yaitu 39,44 MPa dan 37,56 MPa, dimana hasil kuat tekan ini tidak masuk dalam kuat tekan yang disyarakatkan (f'c) sebesar 41,7 MPa.

Tabel 19. Hasil Kuat Tekan Semua Variasi Bottom Ash dengan Tambahan Variasi Silica Fume dan Superplasticizer

\begin{tabular}{|c|c|c|c|c|c|c|}
\hline \multirow[b]{2}{*}{ Hari } & \multicolumn{6}{|c|}{ Kuat Tekan Beton (MPa) } \\
\hline & $\begin{array}{l}\text { Beton } \\
\text { Normal } \\
(0 \%)\end{array}$ & $\begin{array}{c}\text { Beton } \\
\text { Variasi } \\
\text { BA 5\% } \\
+ \text { SF } \\
2 \%+ \\
\text { SP 2\% }\end{array}$ & $\begin{array}{c}\text { Beton } \\
\text { Variasi } \\
\text { BA } \\
10 \%+ \\
\text { SF } 4 \% \\
+ \text { SP } \\
2 \%\end{array}$ & $\begin{array}{c}\text { Beton } \\
\text { Variasi } \\
\text { BA } \\
15 \%+ \\
\text { SF 6\% } \\
+ \text { SP } \\
2 \%\end{array}$ & $\begin{array}{c}\text { Beton } \\
\text { Variasi } \\
\text { BA } \\
20 \%+ \\
\text { SF } 8 \% \\
+ \text { SP } \\
2 \%\end{array}$ & $\begin{array}{c}\text { Beton } \\
\text { Variasi } \\
\text { BA } \\
25 \% \\
+ \text { SF } \\
10 \% \\
+ \text { SP } \%\end{array}$ \\
\hline 7 & 31,04 & 36,42 & 33,50 & 31,23 & 30,29 & 28,78 \\
\hline 14 & 35,10 & 43,97 & 37,84 & 35,29 & 33,22 & 32,37 \\
\hline 28 & 41,89 & 49,82 & 44,35 & 42,46 & 39,44 & 37,56 \\
\hline
\end{tabular}

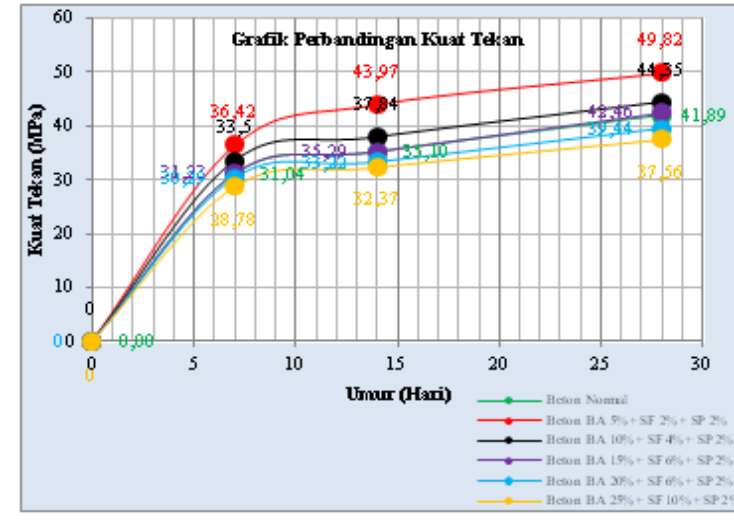

Gambar 4. Grafik Perbandingan Kuat Tekan Semua Variasi Bottom Ash dengan Tambahan Variasi Silica Fume dan Superplasticizer

\section{Setting Time}

a. Setting Time Beton Variasi Campuran Fly Ash dengan Tambahan Variasi Silica Fume dan Superplasticizer

Berdasarkan pembacaan Gambar 5 dapat dilihat bahwa untuk waktu tercepat initial setting adalah pada waktu 251 menit terdapat pada beton abu FA $5 \%+$ SF $2 \%+$ SP $2 \%$.Untuk waktu initial setting terlama terdapat pada beton FA 25\% + SF 10\% + SP $2 \%$. Perbedaan initial setting ini disebabkan karena, semakin banyak kadar abu terbang (fly ash) yang digunakan pada campuran beton, akan membuat initial setting beton menjadi lama.

Tabel 20. Perbandingan Setting Time Beton Semua Variasi Campuran Abu Terbang (Fly Ash) dengan Tambahan Variasi Silica Fume dan Superplasticizer

\begin{tabular}{|c|c|c|c|c|c|c|c|c|c|c|c|c|c|c|}
\hline \multirow[t]{2}{*}{ No } & \multirow{2}{*}{$\begin{array}{l}\text { Umur } \\
\text { Menit }\end{array}$} & \multirow{2}{*}{$\begin{array}{l}\text { Luas } \\
\text { Penp } \\
\text { Sq/in }\end{array}$} & \multicolumn{2}{|c|}{ Beton Normal } & \multicolumn{2}{|c|}{$\begin{array}{c}\mathrm{FA} 5 \%+\mathrm{SF} 2 \%+ \\
\mathrm{SP} 2 \%\end{array}$} & \multicolumn{2}{|c|}{$\begin{array}{c}\mathrm{FA} 10 \%+\mathrm{SF} 4 \%+ \\
\text { SP } \% .\end{array}$} & \multicolumn{2}{|c|}{$\begin{array}{c}\mathrm{FA} 15 \%+\mathrm{SF} 6 \%+ \\
\text { SP2 } \% .\end{array}$} & \multicolumn{2}{|c|}{$\begin{array}{c}\mathrm{FA} 20 \%+\mathrm{SF} 8 \%+ \\
\text { SP2 } \% .\end{array}$} & \multicolumn{2}{|c|}{$\begin{array}{c}\mathrm{FA} 25 \%+\mathrm{SF} 10 \%+ \\
\text { SP2 } \%\end{array}$} \\
\hline & & & $\begin{array}{l}\text { Penerasi } \\
\text { (Ibf) }\end{array}$ & $\begin{array}{c}\text { Pentr } \\
\text { Resistance } \\
\text { (Psi) } \\
\end{array}$ & $\begin{array}{l}\text { Penetrasi } \\
\text { (Ibf) }\end{array}$ & $\begin{array}{c}\text { Penetration } \\
\text { Resistance } \\
\text { (Psi) }\end{array}$ & $\begin{array}{l}\text { Penetrasi } \\
\text { (Ibf) }\end{array}$ & \begin{tabular}{|c} 
Penetration \\
Resistance \\
(Psi)
\end{tabular} & $\begin{array}{l}\text { Penetrasi } \\
\text { (Ibf) }\end{array}$ & \begin{tabular}{|c} 
Penetration \\
Resistance \\
(Psi)
\end{tabular} & $\begin{array}{l}\text { Penetrasi } \\
\text { (Ibf) }\end{array}$ & \begin{tabular}{|c|} 
Penetration \\
Resistance \\
(Psi)
\end{tabular} & $\begin{array}{l}\text { Penetrasi } \\
\text { (Ibf) }\end{array}$ & $\begin{array}{c}\text { Penetration } \\
\text { Resistance } \\
\text { (Psi) }\end{array}$ \\
\hline 1 & 60 & 1 & 0 & 0 & 0 & 0 & 0 & 0 & 0 & $\begin{array}{l}0 \\
\end{array}$ & 0 & \begin{tabular}{|l|}
0 \\
\end{tabular} & 2 & 2 \\
\hline 2 & 120 & 1 & 22 & 22 & 4 & 4 & 13 & 13 & 16 & 16 & 5 & 5 & 6 & 6 \\
\hline 3 & 150 & $1 / 2$ & 26 & 52 & 20 & 40 & 26 & 26 & 40 & 40 & 50 & 50 & 47 & 47 \\
\hline 4 & 180 & $1 / 2$ & 40 & 80 & 47 & 94 & 37 & 74 & 31 & 62 & 36 & 72 & 40 & 80 \\
\hline 5 & 195 & $1 / 4$ & 26 & 104 & 28 & 112 & 50 & 100 & 44 & 88 & 50 & 100 & 33 & 132 \\
\hline 6 & 210 & $1 / 4$ & 33 & 132 & 45 & 180 & 50 & 200 & 49 & 196 & 14 & 140 & 48 & 192 \\
\hline 7 & 240 & $1 / 4$ & 50 & 200 & 27 & 270 & 25 & 250 & 27 & 270 & 25 & 250 & 29 & 290 \\
\hline 8 & 270 & $1 / 10$ & 36 & 360 & 44 & 440 & 40 & 400 & 22 & 440 & 40 & 400 & 24 & 480 \\
\hline 9 & 300 & $1 / 20$ & 27 & 540 & 28 & 560 & 29 & 580 & 29 & 580 & 28 & 560 & 32 & 640 \\
\hline
\end{tabular}




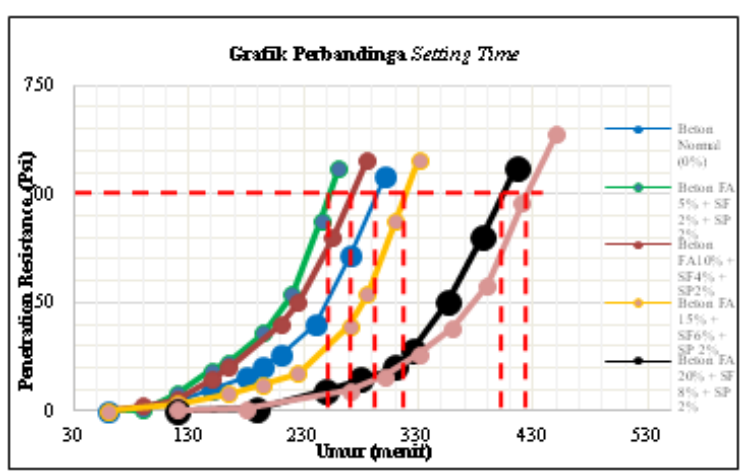

b. Setting Time Beton Variasi Campuran Bottom Ash dengan Tambahan Variasi Silica Fume dan Superplasticizer

Berdasarkan pembacaan Gambar 6 dapat dilihat bahwa untuk waktu tercepat initial setting adalah pada waktu 281 menitterdapat pada BA 5\% + SF 2\% + SP 2\%. Untuk kadar bottom ash yang lebih dari $5 \%$ mengalami waktu yang lama dari beton normal untuk mendapatkan waktu initial settingnya. Dengan demikian, semakin sedikit jumlah kadar bottom ash yang digunakan, akan semakin cepat mendapat titik initial setting.

Gambar 5. Grafik PerbandinganSetting Time Semua

Variasi Campuran Abu Terbang (Fly Ash) dengan

Tambahan Variasi Silica Fume dan Superplasticizer

Tabel 21. Perbandingan Setting Time Beton Semua Variasi Campuran Bottom Ash dengan Tambahan Variasi Silica Fume dan Superplasticizer

\begin{tabular}{|c|c|c|c|c|c|c|c|c|c|c|c|c|c|c|}
\hline \multirow{2}{*}{ No } & \multirow[b]{2}{*}{$\begin{array}{l}\text { Umur } \\
\text { Menit }\end{array}$} & \multirow{2}{*}{$\begin{array}{l}\text { Luas } \\
\text { Penp } \\
\text { Sq/in }\end{array}$} & \multicolumn{2}{|c|}{ Beton Normal } & \multicolumn{2}{|c|}{$\mathrm{FA} 5 \%+\mathrm{SF} 2 \%+\mathrm{SP} 2 \%$} & \multicolumn{2}{|c|}{$\begin{array}{c}\text { FA10 } \%+\text { SF } 4 \%+ \\
\text { SP2 } \% .\end{array}$} & \multicolumn{2}{|c|}{$\begin{array}{c}\text { FA15\% + SF6\% + } \\
\text { SP2\%. }\end{array}$} & \multicolumn{2}{|c|}{$\begin{array}{c}\text { FA20\% + SF } 8 \%+ \\
\text { SP2 } \% .\end{array}$} & \multicolumn{2}{|c|}{$\begin{array}{c}\text { FA25\% + SF10\% + } \\
\text { SP2\%. }\end{array}$} \\
\hline & & & $\begin{array}{l}\text { Penerasi } \\
(\mathrm{Ibf})\end{array}$ & $\begin{array}{c}\text { Pentr } \\
\text { Resistance } \\
\text { (Psi) }\end{array}$ & $\begin{array}{l}\text { Penetrasi } \\
\text { (Ibf) }\end{array}$ & $\begin{array}{l}\text { Penetration } \\
\text { Resistance } \\
\text { (Psi) }\end{array}$ & $\begin{array}{l}\text { Penetrasi } \\
\text { (Ibf) }\end{array}$ & $\begin{array}{l}\text { Penetration } \\
\text { Resistance } \\
\text { (Psi) }\end{array}$ & $\begin{array}{l}\text { Penetrasi } \\
\text { (Ibf) }\end{array}$ & $\begin{array}{l}\text { Penetration } \\
\text { Resistance } \\
\text { (Psi) }\end{array}$ & $\begin{array}{l}\text { Penetrasi } \\
\text { (Ibf) }\end{array}$ & $\begin{array}{l}\text { Penetration } \\
\text { Resistance } \\
\text { (Psi) }\end{array}$ & $\begin{array}{l}\text { Penetrasi } \\
\text { (Ibf) }\end{array}$ & $\begin{array}{l}\text { Penetration } \\
\text { Resistance } \\
\text { (Psi) }\end{array}$ \\
\hline 1 & 60 & 1 & 0 & 0 & 0 & 0 & 0 & 0 & 0 & 0 & 3 & 3 & 5 & 5 \\
\hline 2 & 120 & 1 & 22 & 22 & 30 & 30 & 10 & 10 & 10 & 10 & 28 & 28 & 30 & 30 \\
\hline 3 & 150 & $1 / 2$ & 26 & 52 & 50 & 50 & 42 & 42 & 22 & 22 & 50 & 50 & 45 & 45 \\
\hline 4 & 180 & $1 / 2$ & 40 & 80 & 38 & 76 & 27 & 54 & 50 & 50 & 39 & 78 & 33 & 66 \\
\hline 5 & 195 & $1 / 4$ & 26 & 104 & 50 & 100 & 42 & 84 & 35 & 70 & 50 & 100 & 44 & 88 \\
\hline 6 & 210 & $1 / 4$ & 33 & 132 & 33 & 132 & 29 & 116 & 50 & 100 & 35 & 140 & 34 & 136 \\
\hline 7 & 240 & $1 / 4$ & 50 & 200 & 19 & 190 & 48 & 192 & 50 & 200 & 50 & 200 & 26 & 260 \\
\hline 8 & 270 & $1 / 10$ & 36 & 360 & 31 & 310 & 33 & 330 & 38 & 380 & 35 & 350 & 38 & 380 \\
\hline 9 & 300 & $1 / 20$ & 27 & 540 & 26 & 520 & 25 & 500 & 28 & 560 & 30 & 600 & 27 & 540 \\
\hline
\end{tabular}

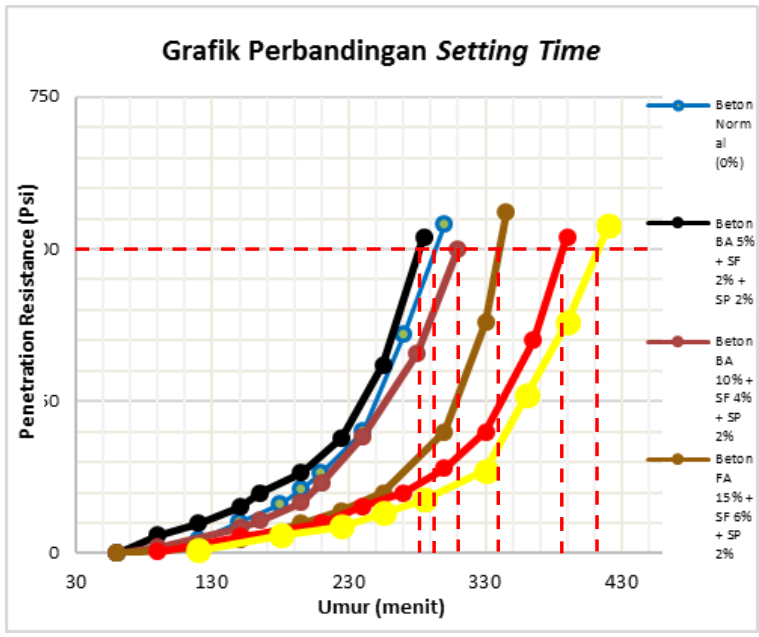

Gambar 6. Grafik Setting Time Semua Variasi Campuran Bottom Ash dengan Tambahan Variasi Silica Fume dan Superplasticizer

\section{Kesimpulan}

1. Limbah abu terbang (fly ash) dapat digunakan untuk bahan alternatif pada campuran beton dengan kadar abu terbang (fly ash) yang baik tidak lebih dari $10 \%$ dari berat semen.
2. Limbah bottom ash dapat digunakan untuk bahan alternatif pada campuran beton dengan kadar bottom ash yang baik tidak lebih dari 5\%.

3. Dari beberapa variasi campuran abu terbang (fly ash) diperoleh suhu maximum $37^{\circ} \mathrm{C}$ dan suhu minimum $33^{\circ} \mathrm{C}$, sedangkan untuk bottom ash suhu maximum $37^{\circ} \mathrm{C}$ dan suhu minimum $34^{\circ} \mathrm{C}$.

4. Berdasarkan hasil uji kuat tekan beton, untuk beton campuran FA $10 \%$, SF $4 \%$, SP $2 \%$ memiliki kuat tekan naik $25,41 \%$ dari beton normal.

5. Berdasarkan hasil uji kuat tekan beton, untuk beton campuran BA 5\%, SF 2\%, SP $2 \%$ memiliki kuat tekan naik $15,92 \%$ dari beton normal.

6. Setting time pada beton campuran FA 5\%, SF $2 \%$, SP $2 \%$ memiliki waktu tercepat initial setting yaitu 251 menit.

7. Setting time pada beton campuran BA $5 \%, \mathrm{SF}$ $2 \%$, SP $2 \%$ memiliki waktu tercepat initial setting yaitu 291 menit.

8. Pada penambahan kadar abu terbang (fly ash), bottom ash, silica fume yang semakin meningkat, akan mengakibatkan waktu beton untuk mencapai initial setting pada setting time semakin lama. 


\section{DAFTAR PUSTAKA}

[1] Badan Standarisasi Nasional. (2013). SNI 032847-2013 Persyaratan Beton Struktural Untuk Bangunan Gedung. Bandung: Badan Standarisasi Nasional

[2] Badan Standarisasi Nasional. (2002). SNI 032847-2002 Tata Cara Perhitungan Struktur Untuk Bangunan Gedung. Bandung: Badan Standarisasi Nasional

[3] Badan Standarisasi Nasional. (2000). Tata Cara Pembuatan Rencana Campuran Beton Normal. SNI 03-2834-2000

[4] Annual book of ASTM Standard. Designation C 33 - 93. Standard Specification for Concrete Aggregates.
[5] Badan Standarisasi Nasional. (2002). SNI 036820-2002 Spesifikasi Agregat Halus Untuk Pekerjaan Adukan Dan Plesteran Dengan Bahan Dasar Semen. Bandung: Badan Standarisasi Nasional.

[6] Badan Standarisasi Nasional. (2000). SNI 032834-2000 Tata Cara Pembuatan Rencana Campuran Beton Normal. Bandung: Badan Standarisasi Nasional.

[7] Badan Standarisasi Nasional. (2002). SNI 036820-2002 Spesifikasi Agregat Halus Untuk Pekerjaan Adukan Dan Plesteran Dengan Bahan Dasar Semen. Bandung: Badan Standarisasi Nasional. 